\title{
1 Refining the planktic foraminiferal I/Ca proxy: results from the Southeast
}

\section{Atlantic Ocean}

3

Wanyi Lu ${ }^{1}$, Alexander J. Dickson ${ }^{2}$, Ellen Thomas ${ }^{3,4}$, Rosalind E.M. Rickaby ${ }^{5}$, Piers Chapman ${ }^{6}$ and Zunli $\mathrm{Lu}^{1} *$

1 Department of Earth Sciences, Syracuse University, Syracuse, NY, USA

2 Department of Earth Sciences, Royal Holloway University of London, Egham, UK

3 Department of Geology and Geophysics, Yale University, New Haven, CT, USA

4 Department of Earth and Environmental Sciences, Wesleyan University, Middletown, CT, USA

5 Department of Earth Sciences, University of Oxford, Oxford, UK

6 Department of Oceanography, Texas A\&M University, College Station, TX, USA

*Correspondence to: zunlilu@syr.edu

\section{Abstract}

Profound changes in upper ocean oxygenation have taken place in recent decades and are expected to continue in the future, but the complexity of the processes driving these changes has yet to be fully unraveled. Planktic foraminiferal $\mathrm{I} / \mathrm{Ca}$ is a promising tool to reconstruct the extent of past upper ocean oxygenation, but a thorough assessment is necessary to evaluate both its potential and its limitations. We used foraminifers from Holocene core-tops (Southeast Atlantic Ocean) to document planktic I/Ca across a range of oceanographic conditions. Subsurface $\mathrm{O}_{2}$ concentrations may be the dominant control on planktic foraminiferal $\mathrm{I} / \mathrm{Ca}$ and planktic $\mathrm{I} / \mathrm{Ca}$ decreases rapidly at low $\mathrm{O}_{2}$ conditions $\left(\mathrm{O}_{2}<\sim 70-100 \mu \mathrm{mol} / \mathrm{kg}\right)$. We thus document that low planktic I/Ca can be used empirically to indicate hypoxia in the upper water column, but questions remain as to the mechanistic understanding of the relation between seawater iodine speciation change, its $\mathrm{O}_{2}$ threshold and foraminiferal $\mathrm{I} / \mathrm{Ca}$. Planktic $\mathrm{I} / \mathrm{Ca}$ records from core 
28 GeoB1720-2 (Benguela Upwelling System, SE Atlantic) suggest that hypoxic waters were

29 present near the site persistently during the last $240 \mathrm{ka}$, without clear glacial-interglacial 30 variability.

\section{Introduction}

The carbonate I/Ca proxy as used on planktic foraminifera has great potential to reconstruct

34 upper ocean oxygenation changes, for which few proxies are available (Hoogakker et al., 2018; Lu et al., 2018; Lu et al., 2016). Inorganic iodine in the oceans exists as two thermodynamically stable species: iodate $\left(\mathrm{IO}_{3}^{-}\right.$, oxidized form) and iodide ( $\mathrm{I}^{-}$, reduced form), and the equilibration between the two species is highly redox-sensitive. Iodate is completely reduced to iodide in anoxic waters, and re-oxidized under well-oxygenated conditions (Rue et al., 1997). Only $\mathrm{IO}_{3}{ }^{-}$is incorporated into the calcite structure (Lu et al., 2010) by substituting for the $\mathrm{CO}_{3}{ }^{2-}$ ion (Feng and Redfern, 2018; Podder et al., 2017). Higher foraminiferal I/Ca values thus generally record higher $\mathrm{IO}_{3}{ }^{-}$concentrations in seawater, and therefore indicate better-oxygenated water conditions. Planktic foraminiferal $\mathrm{I} / \mathrm{Ca}$ has been shown to primarily record upper ocean oxygenation (Hoogakker et al., 2018; Lu et al., 2016; Zhou et al., 2014). A threshold value (I/Ca $<2.5$ $\mu \mathrm{mol} / \mathrm{mol}$ ) was proposed to indicate low $\mathrm{O}_{2}$ upper ocean waters, based on a limited number of globally-distributed core-top foraminiferal samples (Lu et al., 2016). We collected more core-top data to further elucidate the behavior of I/Ca across different oxygenation windows: anoxic $\left(\mathrm{O}_{2}=\right.$ 0), suboxic $\left(\mathrm{O}_{2}<10 \mu \mathrm{mol} / \mathrm{kg}\right)$, hypoxic $\left(\mathrm{O}_{2}<\sim 70-100 \mu \mathrm{mol} / \mathrm{kg}\right)$, and oxic $\left(\mathrm{O}_{2}>100 \mu \mathrm{mol} / \mathrm{kg}\right)$.

Planktic I/Ca and bulk sediment nitrogen isotopes $\left(\delta^{15} \mathrm{~N}\right)$ both have been used to indicate low 
$49 \mathrm{O}_{2}$ conditions in the upper water column. One of the motivations of this study is to compare and 50 differentiate the behavior of planktic I/Ca and bulk $\delta^{15} \mathrm{~N}$ across hypoxic and suboxic windows. In 51 suboxic waters (e.g., eastern tropical Pacific and Arabian Sea), water column denitrification 52 preferentially removes ${ }^{14} \mathrm{~N}$, leaving the residual nitrate enriched in ${ }^{15} \mathrm{~N}$, thus bulk $\delta^{15} \mathrm{~N}$ is interpreted to reflect the relative degree of water column denitrification under suboxic conditions

54 (Altabet et al., 1999; Galbraith et al., 2013; Robinson et al., 2009). In areas of incomplete nitrate 55 consumption on surface waters (e.g., high nutrient regions), bulk $\delta^{15} \mathrm{~N}$ signals are generally thought to reflect relative degrees of nitrate utilization by the phytoplankton community

57 (Galbraith and Jaccard, 2015; Galbraith et al., 2008; Pichevin et al., 2005b). Therefore, a study of planktic foraminiferal $\mathrm{I} / \mathrm{Ca}$ in low oxygen regions of the Atlantic where there is no water column denitrification should provide new insights into these two oxygen proxies targeting a similar part

60

61

62

63

64

65

66

67

68

69

of the water column.

Ocean deoxygenation has been observed in large areas of the Southeast Atlantic Ocean in the past five decades (Schmidtko et al., 2017). Previous studies reconstructed glacial-interglacial histories of sea surface temperature (SST) (e.g., Farmer et al. (2005); Mollenhauer et al. (2003); Pichevin et al. (2005a)) and primary productivity (e.g., Mollenhauer et al. (2002); Romero et al. (2015)), but few studies focused on reconstructing water column oxygenation (e.g., McKay et al. (2016)). Information on glacial-interglacial changes in oceanic oxygenation may help inform us on the extent of and controls on potential future ocean deoxygenation.

We report I/Ca data on eight planktic foraminiferal species (depth habitats from near-surface to the thermocline) in 19 core-tops from the Southeast Atlantic Ocean (Southwest African margin, 
70 Fig. 1). We aim to better constrain the signal of planktic foraminifera $\mathrm{I} / \mathrm{Ca}$ in hypoxic as

71 compared to suboxic hydrographic regimes. In addition, we show a downcore I/Ca record of

72 GeoB1720-2 (28 59'S, 1350'E, $1997 \mathrm{~m})$ within the Benguela Upwelling System (BUS), and

73 compare it to a bulk sediment $\delta^{15} \mathrm{~N}$ record from the BUS (Pichevin et al., 2005b) to reconstruct

74 the upper water column conditions over the last two glacial cycles.

75

\section{2. Samples and Methods}

$77 \quad 2.1$. Study site upwelling of nutrient rich waters and the resulting high productivity, particularly in the BUS (Chapman and Shannon, 1985; Jarre et al., 2015). The BUS is bounded to the North by the

81 Angola-Benguela frontal zone (between 14 and $17^{\circ} \mathrm{S}$ ), to the South by the Agulhas retroflection

82 (around $37^{\circ} \mathrm{S}$ ) (Shannon and Nelson, 1996), and is one of the most highly productive regions in

83 the world oceans. Wind-driven upwelling of nutrient-rich waters along the west coast of southern

84 Africa is important for marine biodiversity and food production (Chapman and Shannon, 1985;

85 Jarre et al., 2015). Mutually inconsistent observations have been made indicating the occurrence

86 of (Hutchings et al., 2009) or lack of (Pitcher et al., 2014) long-term oxygen decline in the 87 coastal waters in the BUS since the 1960s.

Shelf water along the west coast of southern Africa commonly contains low dissolved $\mathrm{O}_{2}$

89 (e.g., $<2 \mathrm{ml} / \mathrm{l}$, approximately $<90 \mu \mathrm{mol} / \mathrm{kg}$ ), and the $\mathrm{O}_{2}$ concentrations vary significantly

90 spatially (Fig. 1, 2). Upper ocean waters close to the southwest African coast are affected by both 
91 the southward Poleward Undercurrent (PUC), down to $200 \mathrm{~m}$ depth along the shelf break, and by

92 the northward Benguela Current, further offshore, down to $1200 \mathrm{~m}$ depth. The Benguela Current

93 forms the eastern limb of the South Atlantic gyre, and contains water from the South Atlantic

94 Current with additional inputs of warm, salty Indian Ocean water from the Agulhas Current

95 (Stramma and England, 1999). The PUC originates from the Equatorial Undercurrent and the

96 Angola Gyre, and transports low oxygen waters southward along the shelf north of $27^{\circ} \mathrm{S}$ (Fig. 1).

97 The low $\mathrm{O}_{2}$ conditions of the BUS in the coastal area between $30^{\circ} \mathrm{S}$ and $34^{\circ} \mathrm{S}$ are most likely due

to local decomposition of organic matter (Chapman and Shannon, 1985) (Fig. 1, 2).

99

Site GeoB1720-2 is located on the Southwest African slope within the northward path of the

100

101

102

103

104

105

106

107

108

109

110

111

Benguela Current (Fig. 1, 2). The upper ocean hydrography over this site is affected by the upwelling of South Atlantic Central Water close to the African coast, Agulhas leakage of tropical Indian Ocean waters, and subantarctic waters from large-scale eddy mixing at the subtropical front $\left(\sim 42^{\circ} \mathrm{S}\right)$ (Dickson et al., 2010; Stramma and England, 1999).

\subsection{Samples materials}

A total of 19 core-top samples were obtained from the upper $5 \mathrm{~cm}$ of cores from the Lamont-Doherty Core Repository (Table S1). The core-top sediments were wet-sieved to the > $63 \mu \mathrm{m}$ fraction with MilliQ water, then oven-dried at $40^{\circ} \mathrm{C}$. Specimens from eight planktic foraminiferal species (Globigerinoides ruber, Neogloboquadrina incompta, Globigerina bulloides, Globorotalia truncatulinoides (sinistral and dextral), Globigerinoides sacculifer, Globorotalia inflata, Neogloboquadrina dutertrei, and Globorotalia menardii) were picked, and 
112 25-80 individuals from the 150-300 $\mu \mathrm{m}$ size fraction were used for I/Ca analyses. Two species, $G$.

113 truncatulinoides (sinistral) and $N$. incompta, were picked from sieved sediments from core

114 GeoB1720-2. Around 25 specimens of G. truncatulinoides (sinistral) and $\sim 80$ specimens of $N$.

115 incompta from 150-300 $\mu \mathrm{m}$ size fraction were used for I/Ca analyses.

116

117 2.3. Age model

118 Radiocarbon dating of the planktic foraminifer $G$. inflata from selected samples shows a

119 Holocene age (Table S1). Radiocarbon was analyzed at the Keck Carbon Cycle AMS Facility at

120 University of California, Irvine. The age model of core GeoB1720-2 is based on nine AMS ${ }^{14} \mathrm{C}$

121 dates between 0 and $200 \mathrm{~cm}$ depth for the planktic foraminifer G. inflata (Dickson et al., 2009),

122 and is extended down-core by tying the $N$. incompta $\delta^{18} \mathrm{O}$ stratigraphy to the global benthic

123 foraminiferal $\delta^{18} \mathrm{O}$ stack (Lisiecki and Raymo, 2005) between 200 and $900 \mathrm{~cm}$ depth (Fig. S1

124 and Table S2), assuming the GeoB1720-2 $\delta^{18} \mathrm{O}$ record can be correlated to the global stack. The

$125 N$. incompta $\delta^{18} \mathrm{O}$ data for core GeoB1720-2 are here first reported. They were measured on the

$126150-250 \mu \mathrm{m}$ size fraction from homogenized sample sizes of $\sim 20$ individuals on a Thermo

127 MAT Delta V Advantage mass spectrometer coupled to a Kiel Device at the Department of Earth

128 Sciences, University of Cambridge, and the Department of Physical Sciences, The Open

129 University. Calibration to Vienna Pee Dee Belemnite was via NBS19 standards. Precision is $130 \pm 0.1 \%$ (1 S.D.).

131

\section{2.4. Foraminiferal I/Ca analyses}

133 The foraminiferal I/Ca analytical methods follow Lu et al. (2016). The samples were gently 
crushed with cleaned glass slides to open all chambers of the tests. Samples were cleaned by ultrasonication in MilliQ water to remove clays, a 10-minute boiling-water bath in $\mathrm{NaOH}$-buffered $1 \% \mathrm{H}_{2} \mathrm{O}_{2}$ solutions to remove organic matter, and 3 additional rinses with MilliQ water. The cleaned samples were dissolved in $3 \% \mathrm{HNO}_{3}$, and diluted to solutions with $\sim 50 \mathrm{ppm}$ Ca for analyses. A $0.1 \%$ tertiary amine solution was added to stabilize iodine in solution. The measurements were performed immediately, to minimize potential iodine loss due to iodine speciation change and volatilization. The I/Ca analyses were performed on a quadrupole ICP-MS (Bruker M90) at Syracuse University. The sensitivity of I-127 is tuned to $100-120$ kcps for a 1 ppb standard. The reference standard JCp-1 ( $\mathrm{I} / \mathrm{Ca}$ value of $4.27 \mu \mathrm{mol} / \mathrm{mol}$ ) was analyzed repeatedly to monitor long-term accuracy ( $\mathrm{Lu}$ et al., 2010). The detection limit of I/Ca is on the order of $0.1 \mu \mathrm{mol} / \mathrm{mol}$. Replicates of selected $G$. truncatulinoides (sinistral) from core 145 GeoB1720-2 yielded a reproducibility ranging from $\pm 3 \%(0.03 \mu \mathrm{mol} / \mathrm{mol} ; 1 \sigma)$ to $\pm 10 \%(0.15$ $146 \mu \mathrm{mol} / \mathrm{mol} ; 1 \sigma)$ for I/Ca (Table S3).

\subsection{Planktic foraminiferal habitat}


$154 \sim 300 \mathrm{~m}$ (winter) for G. truncatulinoides (dextral) in multi-core GeoB1720-3 (2859’S, 1350’E, $1552004 \mathrm{~m}$ ) (Dickson et al., 2010). This core is located within a few meters of GeoB1720-2, thus the 156 data are broadly applicable to our study region.

\subsection{Hydrographic data}

Oxygen data for core-top sites were obtained from high-resolution CTD profiles in the

167 column is used because $\mathrm{O}_{2}$ has to drop below a certain threshold to trigger iodate reduction,

\section{Results}


175 tropical and Southern BUS regions, which generally contain hypoxic waters at mid-depths or 176 bottom depths $\left(\mathrm{O}_{2}<\sim 70-100 \mu \mathrm{mol} / \mathrm{kg}\right)$ (Fig. 3 and 4). High core-top I/Ca values $(>\sim 4$ $177 \mu \mathrm{mol} / \mathrm{mol})$, regardless of species, are found in the Walvis Ridge region, where waters generally 178 are well oxygenated $\left(\mathrm{O}_{2}>\sim 100 \mu \mathrm{mol} / \mathrm{kg}\right)$.

179 We do not observe any consistent or systematic differences in $\mathrm{I} / \mathrm{Ca}$ between 180 symbiont-bearing species (G. ruber and G. sacculifer) and symbiont-barren species (G. menardii, 181 N. dutertrei, N. incompta, G. bulldoides, G. inflata, G. truncatulinoides) within the same 182 core-top sample (Fig. S2). At Southern BUS (low oxygen region), symbiont-barren species 183 record slightly wider ranges of $\mathrm{I} / \mathrm{Ca}$ and the average $\mathrm{I} / \mathrm{Ca}$ of symbiont-barren species are lower 184 than the average values of symbiont-bearing species in two out of three core-top samples. In the 185 high oxygen Walvis Ridge region, I/Ca values in three out of four samples show similar ranges 186 and variabilities in symbiotic vs. non-symbiotic species, except for one sample with notably smaller variability in symbiotic species.

Higher core-top I/Ca values are generally associated with higher $\mathrm{O}_{2}$ conditions in the water 189 column as estimated from the nearest site in the WOD2013 database (Fig. 5), consistent with Lu 190 et al. (2016). At three sites in the Southern BUS region (V19-238, V19-228, and V14-70, see Table S1 for details), however, high modern minimum $\mathrm{O}_{2}$ concentrations $(150-220 \mu \mathrm{mol} / \mathrm{kg})$ apparently are associated with low $\mathrm{I} / \mathrm{Ca}(<\sim 2 \mu \mathrm{mol} / \mathrm{mol})$, but the $\mathrm{O}_{2}$ values around these core-top sites are highly variable spatially (Fig. 2).

In the downcore record of GeoB1720-2, almost all G. truncatulinoides (sinistral) and $N$. incompta $\mathrm{I} / \mathrm{Ca}$ values are $<2.5 \mu \mathrm{mol} / \mathrm{mol}$ during the last two glacial cycles (Fig. 6). 


\section{4. Discussion}

\section{$198 \quad$ 4.1. Subsurface $\mathbf{O}_{2}$ conditions}

199 Measurements of the core-top samples in the Southeast Atlantic Ocean confirmed that low 200 planktic I/Ca values can reveal the presence of low- $\mathrm{O}_{2}$ waters in the upper ocean (Fig. 5c), as 201 previously demonstrated ( $\mathrm{Lu}$ et al., 2016). However, we also found high $\mathrm{O}_{2}$ - low I/Ca values in 202 the Southern BUS region (Fig. 5c), which may be explained by different scenarios: (1) $\mathrm{O}_{2}$ values 203 from the WOD2013 do not represent the actual conditions during foraminiferal growth, due to 204 short-term or spatial variability of $\mathrm{O}_{2} ;(2)$ the foraminifera calcified in high $\mathrm{O}_{2}-\mathrm{low}_{\mathrm{IO}_{3}}{ }^{-}$water, 205 due to slow kinetics of $\mathrm{I}^{-}$oxidation; (3) the planktic foraminifera lived at nearby locations with 206 lower $\mathrm{O}_{2}$ and were transported to their current sites (Fig. 2); (4) unknown factors are limiting $207 \mathrm{IO}_{3}{ }^{-}$uptake by foraminifera at these sites.

Examining the first of these possibilities, hypoxic waters are common in the shelf areas of 209 the BUS system and their extent and level of oxygen depletion vary spatially and on seasonal, 210 interannual, and decadal timescales (Jarre et al., 2015). Significant vertical and seasonal changes 211 in water column oxygen concentrations are more likely in the nearshore than in the offshore 212 regions (Lamont et al., 2015; Pitcher et al., 2014). However, episodic hypoxic conditions in the 213 water column have been reported offshore of the BUS (Pitcher et al., 2014), and may provide 214 low $\mathrm{O}_{2}$ water at our core-top sites not captured in the WOD2013 dataset, which does not 215 comprise seasonal or annual $\mathrm{O}_{2}$ measurements in the Southern BUS region. The $\mathrm{O}_{2}$ data in 216 WOD2013 also span a considerable time period, representing an additional source of uncertainty. 
217 Thus the uncertainty arising from modern measurements of $\mathrm{O}_{2}$ and its short-term variability may 218 at least partially explain the high $\mathrm{O}_{2}$ - low $\mathrm{I} / \mathrm{Ca}$ cases in the Southern BUS region.

219 In addition, the high $\mathrm{O}_{2}$ - low I/Ca cases in the Southern BUS region may be related to the 220 slow kinetics of iodide re-oxidation. Estimated $\mathrm{I}^{-}$oxidation rates range from 4 to $670 \mathrm{nM}$ per 221 year, whereas reduction of $\mathrm{IO}_{3}{ }^{-}$at an anoxic boundary is rapid ( $\sim 50 \mathrm{nM}$ per hour) (Chance et al., 222 2014). Shelf waters in the Southern BUS (all water depths $<200 \mathrm{~m}$ ) were reported to have highly 223 variable $\mathrm{O}_{2}$ concentrations $(10-400 \mu \mathrm{mol} / \mathrm{kg})$ but low $\mathrm{IO}_{3}{ }^{-}$concentrations $(<\sim 0.25 \mu \mathrm{M})(\mathrm{Fig}$. 5b) 224 (Chapman, 1983). Intense water column mixing in the shelf region of Southern BUS may bring 225 bottom waters with low $\mathrm{IO}_{3}{ }^{-}$signals from peripheral locations into the photic zone, where the concentrations of nutrients and chlorophyll $\alpha$ are exceptionally high (Truesdale and Bailey, 2000).

227 During this transport, oxygen concentrations may have begun to rise due to photosynthesis or 228 mixing with $\mathrm{O}_{2}$-rich waters, but the $\mathrm{IO}_{3}{ }^{-}$concentration remained low due to the slow oxidation of $\mathrm{I}^{-}$(Chapman, 1983; Truesdale and Bailey, 2000).

Central to these different scenarios for the occurrence of high $\mathrm{O}_{2}-$ low $\mathrm{I} / \mathrm{Ca}$ in the Southern BUS is the key concept that low foraminiferal $\mathrm{I} / \mathrm{Ca}$ may reflect low $\mathrm{O}_{2}$ conditions that vary on small space- and time-scales. To visualize such a spatial uncertainty, we plot I/Ca against minimum $\mathrm{O}_{2}$ values within a $0.25^{\circ} \times 0.25^{\circ}$ area around each core-top location (Fig. 5). All core-top samples with low I/Ca in the Southern BUS come from a region where hypoxia occurs within $0.25^{\circ}$ of the sample site (Fig. 5d). These results caution against the use of planktic I/Ca as a proxy for in-situ $\mathrm{O}_{2}$ conditions, especially in settings with strong hydrographic gradients and mixing. However, we emphasize that these high $\mathrm{O}_{2}$ - low $\mathrm{I} / \mathrm{Ca}$ cases only occurred in the 
238 Southern BUS region with high spatial and temporal variability of $\mathrm{O}_{2}$, and not in the tropical and 239 Walvis Ridge regions.

\subsection{Planktic I/Ca as a hypoxia proxy}

Water column $\mathrm{IO}_{3}^{-}$and $\mathrm{O}_{2}$ profiles from the core-top sites would provide the ideal 243 constraints of the $\mathrm{O}_{2}$ threshold driving the foraminiferal I/Ca signal. However, such modern 244 seawater data are only available for a relatively small area from the Southern BUS (Chapman, 245 1983). In that study, dissolved $\mathrm{IO}_{3}{ }^{-}$concentrations do not correlate with surface $\mathrm{O}_{2}$ (depth $<50$ $246 \mathrm{~m}$ ), but decrease rapidly when $\mathrm{O}_{2}$ in subsurface waters (depth $>50 \mathrm{~m}$ ) approaches $\sim 70-100$ $247 \mu \mathrm{mol} / \mathrm{kg}$ (Fig. 5b). Similarly, our core-top I/Ca data exhibit abrupt decreases when minimum $\mathrm{O}_{2}$ 248 values drop to these levels, with the exception of the above described high $\mathrm{O}_{2}-$ low I/Ca areas 249 (Fig. 5c). This $\mathrm{O}_{2}$ threshold for rapid $\mathrm{IO}_{3}{ }^{-}$or $\mathrm{I} / \mathrm{Ca}$ decrease is generally consistent with the 250 estimates based on globally-distributed core-top foraminifera (Lu et al., 2016).

We suggest that low planktic I/Ca can empirically indicate hypoxia in the upper water 252 column, but it is not clear why planktic I/Ca responds to water column hypoxia, which warrants 253 further discussion. We approach this question from two directions: the relationship between $\mathrm{IO}_{3}{ }^{-}$ 254 and $\mathrm{O}_{2}$ in hypoxic waters, and the relation between $\mathrm{IO}_{3}{ }^{-}$reduction and denitrification. 
oceans OMZs (Farrenkopf and Luther, 2002) (Fig. 5a). However, the Benguela data seem to indicate that $\mathrm{IO}_{3}{ }^{-}$reduction may occur at hypoxic conditions with somewhat higher oxygen levels $\left(\left[\mathrm{O}_{2}\right]<70-100 \mu \mathrm{mol} / \mathrm{kg}\right.$ ) (Fig. 5b), as also found over the shelf in the northern Gulf of Mexico (Chapman and Truesdale, 2011). Maybe, the $\mathrm{O}_{2}$ threshold for seawater $\mathrm{IO}_{3}{ }^{-}$reduction varies across different ocean basins, or there are other processes that control the balance between $\mathrm{IO}_{3}{ }^{-}$and $\mathrm{I}^{-}$in seawater (e.g., the uptake rate of $\mathrm{IO}_{3}{ }^{-}$versus $\mathrm{I}^{-}$by plankton, iodide oxidation rates vary in different oceans). Further work on seawater $\mathrm{IO}_{3}{ }^{-}$and $\mathrm{O}_{2}$ are required to discern these $\mathrm{O}_{2}$ thresholds.

Since $\mathrm{I} / \mathrm{Ca}$ and bulk $\delta^{15} \mathrm{~N}$ can indicate low- $\mathrm{O}_{2}$ conditions in the upper water column and iodate reduction can be carried out by nitrate reductase, we explore some potential connections between $\mathrm{IO}_{3}{ }^{-}$reduction and denitrification. Laboratory cultures have suggested that various types of algae and bacteria are able to reduce iodate to iodide in seawater (Chance et al., 2007; Farrenkopf et al., 1997; Waite and Truesdale, 2003), but the exact mechanisms remain unclear.

272 Nitrate reductase enzymes have been speculated to be responsible for $\mathrm{IO}_{3}{ }^{-}$reduction (Tsunogai 273 and Sase, 1969; Wong and Hung, 2001), but no clear distinction has been made between assimilatory vs. dissimilatory nitrate reductases and their roles in seawater iodine speciation.

275 Assimilatory nitrate reductases are generally associated with nitrate uptake in the euphotic zone 276 (high $\mathrm{O}_{2}$ water) (Wada and Hattori, 1990). Dissimilatory nitrate reductases are considered to 277 function in suboxic conditions, although denitrifying bacteria isolated from marine sediment 278 show nitrate reducing activity at $\mathrm{O}_{2}$ concentrations up to $\sim 124 \mu \mathrm{mol} / \mathrm{kg}$ (Bonin et al., 1989). It 279 may be worth further investigation into the prevalence and distribution of specific nitrate 
reductase enzymes responsible for $\mathrm{IO}_{3}{ }^{-}$reduction and their $\mathrm{O}_{2}$ sensitivities coupled with water column $\mathrm{IO}_{3}{ }^{-}$and $\mathrm{O}_{2}$ concentrations.

Another possibility to explain a hypoxic threshold for rapid I/Ca decrease may involve anaerobic metabolism of microbes (including $\mathrm{IO}_{3}{ }^{-}$reduction) in microenvironments of sinking organic aggregates in oxic-hypoxic water. Denitrification is often described as occurring in suboxic or anoxic waters only (Ulloa et al., 2012), but denitrification and even sulfate-reduction by microbes have been reported at $\mathrm{O}_{2}>20 \mu \mathrm{mol} / \mathrm{kg}$ (Ganesh et al., 2014; Wolgast et al., 1998). Possibly, particle microenvironments in hypoxic waters may have sufficiently low $\mathrm{O}_{2}$ concentrations to support anaerobic metabolism, including denitrification and sulfate reduction (Bianchi et al., 2018) and potentially iodate reduction. These low $\mathrm{IO}_{3}{ }^{-}$signals formed in microenvironments could be subsequently released into ambient hypoxic seawater where the planktic foraminifera calcify. Such a scenario could be an explanation for $\mathrm{IO}_{3}{ }^{-}$reduction in hypoxic water, and I/Ca may be sensitive to water column denitrification in microenvironments.

In summary, we suggest that planktic I/Ca remains an empirical proxy - low I/Ca values can reliably indicate the presence of hypoxia in the water column, in contrast to bulk sediment $\delta^{15} \mathrm{~N}$ as a proxy for denitrification in suboxic water. In future studies, foraminiferal $\mathrm{I} / \mathrm{Ca}$, paired $\mathrm{O}_{2}$ and iodate data from low $\mathrm{O}_{2}$ regions may improve the mechanistic understanding of the proxy and also the marine biogeochemistry of iodine. Iodate will not be used as oxidant until $\mathrm{O}_{2}$ is significantly depleted, but iodate reduction may not necessarily occur in the habitat of calcifying 
301

302

303

304

305

306

307

308

309

310

311

312

313

314

315

316

317

318

319

320

321

diffusion/advection and slow oxidation of iodide. On the other hand, culture experiments show that two modern planktic species (O. universa, symbiotic species, and $G$. bulloides, non-symbiotic species) can survive, add chambers, feed, and undergo gametogenesis in low- $\mathrm{O}_{2}$ conditions ( $22 \mu \mathrm{mol} / \mathrm{L})$ (Kuroyanagi et al., 2013). Some species (N. dutertrei and G. bulloides) can even survive episodic or temporary exposure to $\mathrm{H}_{2} \mathrm{~S}(<24 \mathrm{hr}$ ) (Kuroyanagi et al., 2019). We cannot rule out the possibility that planktic foraminifera may survive in hypoxic waters and directly record a low I/Ca signal. Such foraminifera culture experiments may also be helpful for testing vital effects in different species.

\subsection{Planktic $\mathrm{I} / \mathrm{Ca}$ downcore record in the BUS}

We use the $\mathrm{I} / \mathrm{Ca}$ values in $N$. incompta and $G$. truncatulinoides (sinistral) from core GeoB1720-2 from the Southeast Atlantic to reconstruct the upper water oxygenation history over the last $240 \mathrm{ka}$, and compare these results with $\delta^{15} \mathrm{~N}$ data from nearby site MD96-2087 $\left(25.60^{\circ} \mathrm{S}\right.$, $13.38^{\circ} \mathrm{E}, 1029 \mathrm{~m}$ ) (Pichevin et al., 2005b). The downcore I/Ca values are consistently low, $<2.5$ $\mu \mathrm{mol} / \mathrm{mol}$, over the last two glacial cycles (Fig. 6), indicating the persistent presence of hypoxic waters near the study site (e.g., within $0.25^{\circ} \times 0.25^{\circ}$ area). It is possible that low $\mathrm{IO}_{3}{ }^{-}$water was advected to this site from nearby locations. Nutrient levels, indicated by bulk sediment $\delta^{15} \mathrm{~N}$ records from MD96-2087 (Fig. 6), likewise do not show a clear glacial-interglacial pattern (Pichevin et al., 2005b). The narrow amplitude of this $\delta^{15} \mathrm{~N}$ record was interpreted to reflect that nitrate was never severely depleted over the shelf (Pichevin et al., 2005b). Thus the upwelling dynamics in the near-shore region of BUS may have persistently fueled relatively high levels of 
322 surface nutrient and subsurface hypoxia through glacial-interglacial oscillations, which remained

323 a dominant oceanographic feature in this area. On the other hand, downcore records for excess

$324 \mathrm{Ba}\left(\mathrm{Ba}_{\mathrm{xs}}\right)$ and the $\delta^{13} \mathrm{C}$ difference between $G$. ruber (a summer calcifier) and N. incompta

325 (calcifying below the mixed layer) $\left(\Delta \delta^{13} \mathrm{C}\right)$ suggest changes in organic carbon export and upper

326 ocean nutrient partitioning over the latter part of the last glacial cycle (Fig. 7). Given the very

327 low I/Ca values, it is likely that subtle alternations of enhanced organic matter export and upper

328 ocean mixing (high $\mathrm{Ba}_{\mathrm{xs}}$, low $\Delta \delta^{13} \mathrm{C}$ ) and lower organic matter export with more stratified

329 surface waters (lower $\mathrm{Ba}_{\mathrm{xs}}$, higher $\Delta \delta^{13} \mathrm{C}$ ) could maintain persistently oxygen-depleted

330 subsurface waters during the past $\sim 50 \mathrm{ka}$ (Fig. 7). It is possible that such variations in export

331 production were relatively small, thus insufficient to drive nutrient utilization $\left(\delta^{15} \mathrm{~N}\right)$ and hypoxia

332 patterns $(\mathrm{I} / \mathrm{Ca})$.

333 Upwelling strength may well have an impact on upper ocean oxygenation conditions in the

334 region (Fig. 6). The alkenone-based SSTs at MD96-2087 (Fig. 6) did not exactly follow

335 glacial-interglacial cycles, but were strongly influenced by upwelling activity and wind-strength,

336 as recorded by dust grain size distributions (Pichevin et al., 2005a). Weak upwelling periods at

337 MD96-2087 coincided temporally with relatively weaker hypoxia as indicated by higher I/Ca of

338 G. truncatulinoides in GeoB1720-2 (Fig. 6). Comparing I/Ca records of hypoxic extent with

339 independent proxies for upwelling strengths may be an intriguing future research direction. 


\section{Conclusions}

New core-top I/Ca data in planktic foraminifera from the Southeast Atlantic Ocean are consistent with previous studies, generally showing low I/Ca corresponding to low oxygen in the upper ocean. This study thus further establishes planktic I/Ca as an empirical proxy for hypoxic conditions $\left(\mathrm{O}_{2}<\sim 70-100 \mu \mathrm{mol} / \mathrm{kg}\right)$ in the Southeast Atlantic. Data from the Southern Benguela region show a more complex pattern, and indicate limitations on the use of planktic $\mathrm{I} / \mathrm{Ca}$ as an in-situ $\mathrm{O}_{2}$ proxy for the foraminiferal habitat. In areas with intense mixing/upwelling, seawater signals may be affected by short-term $\mathrm{O}_{2}$ variability and/or potential transport of hypoxia signals at nearby locations due to the slow kinetics of iodide re-oxidation. Future work are required to better understand the mechanistic relationship between iodate, $\mathrm{O}_{2}$ and foraminiferal $\mathrm{I} / \mathrm{Ca}$. The down-core planktic I/Ca record at site GeoB1720-2 suggests that there were no significant glacial-interglacial variations in upper water hypoxic extent within the BUS during the last 240 ka, consistent with bulk $\delta^{15} \mathrm{~N}$ signals at a nearby site. In this region, relatively small temporal variations in $\mathrm{I} / \mathrm{Ca}$ shows a potential connection with upwelling intensity.

\section{Acknowledgements}

We thank Lamont-Doherty Core Repository for providing core-top materials, the Bremen GeoB core repository for curating and providing material from core GeoB1720-2. We also thank Simona Nicoara at Open University for the $\delta^{18} \mathrm{O}$ analysis at core GeoB1720-2. The $\mathrm{O}_{2}$ data in Fig. $5 b$ has been supplied by the Southern African Data Centre for Oceanography (http://sadco.csir.co.za/). This work is supported by NSF grants OCE-1232620 and OCE-1736542 (to ZL), and OCE-1736538 (ET). 
364

365

366 


\section{Figures}

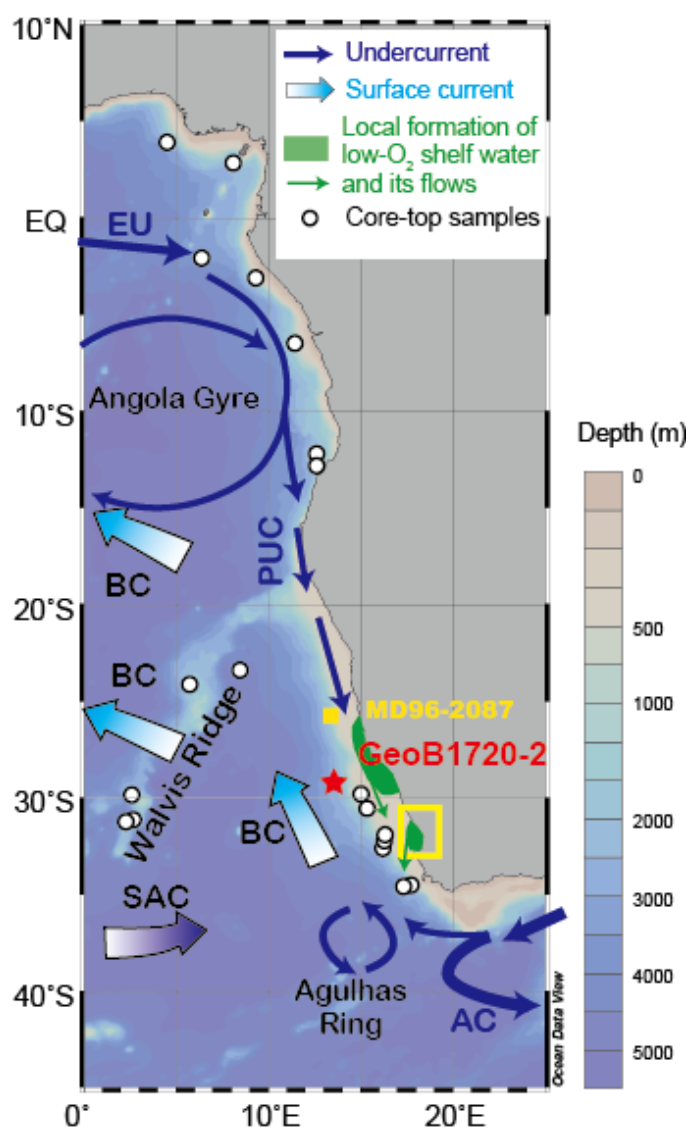

Fig. 1. Locations of core-top samples and site GeoB1720-2. The yellow box marks the sampling area of dissolved iodate and $\mathrm{O}_{2}$ concentrations in seawater in the Southern BUS region in Fig. 5b

372 (Chapman, 1983). The yellow square marks site MD96-2087 in Fig. 6, for comparison with I/Ca 373 records. The upper ocean circulation in the Southeast Atlantic Ocean is modified after Chapman 374 and Shannon (1985) and Stramma and England (1999). EU: Equatorial Undercurrent; PUC: 375 Poleward Undercurrent; BC: Benguela Current; SAC: South Atlantic Current; AC: Agulhas 376 Current. 

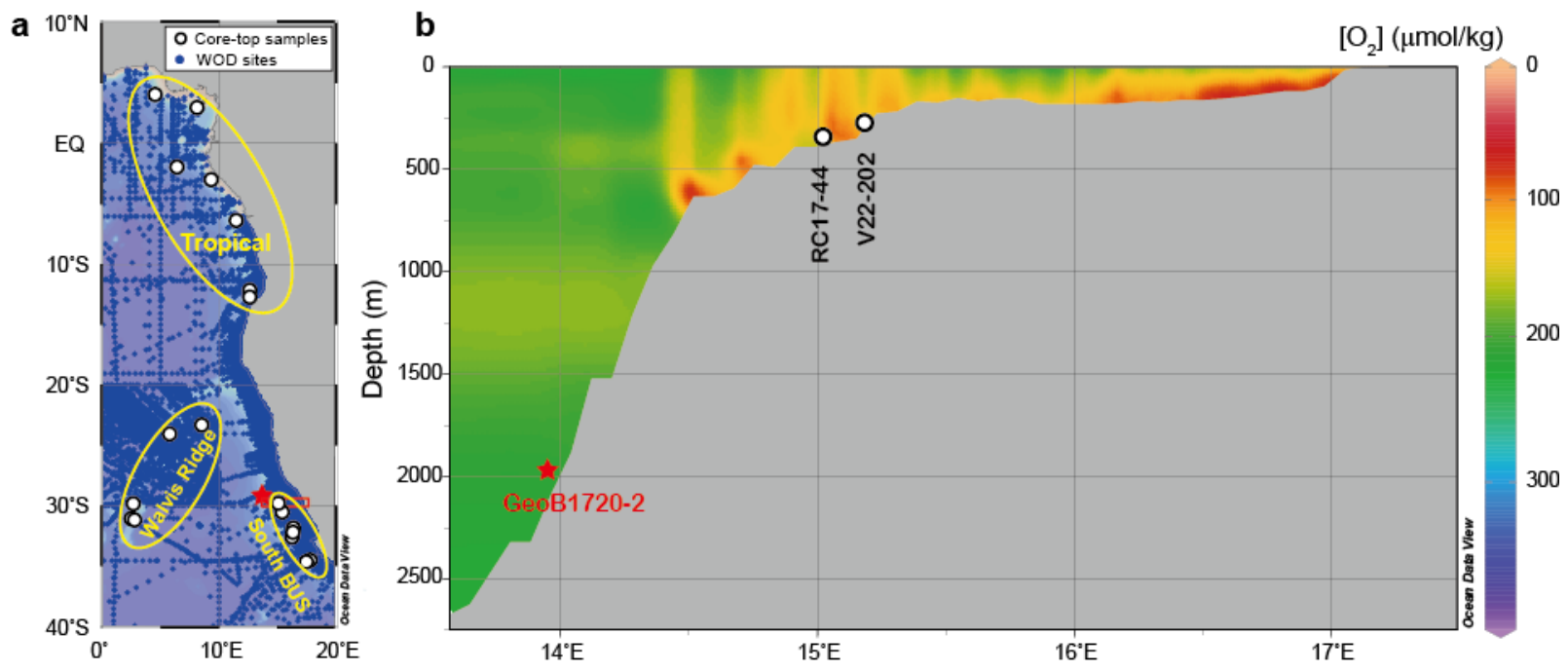

Fig. 2. a). Seawater CTD $\left[\mathrm{O}_{2}\right]$ profile locations in the study area, World Ocean Database (WOD) 3822013 (Boyer et al., 2013). We divided our dataset into three regions, as outlined by the yellow 383 ellipses. b). Cross-section (red box with latitudes between $28^{\circ} 45^{\prime} \mathrm{S}$ and $29^{\circ} 15^{\prime} \mathrm{S}$ ) shows site 384 GeoB1720-2 on the continental slope, and the location of two cores in the coastal area of the 385 BUS, showing significant spatial variation of $\mathrm{O}_{2}$ concentrations. 


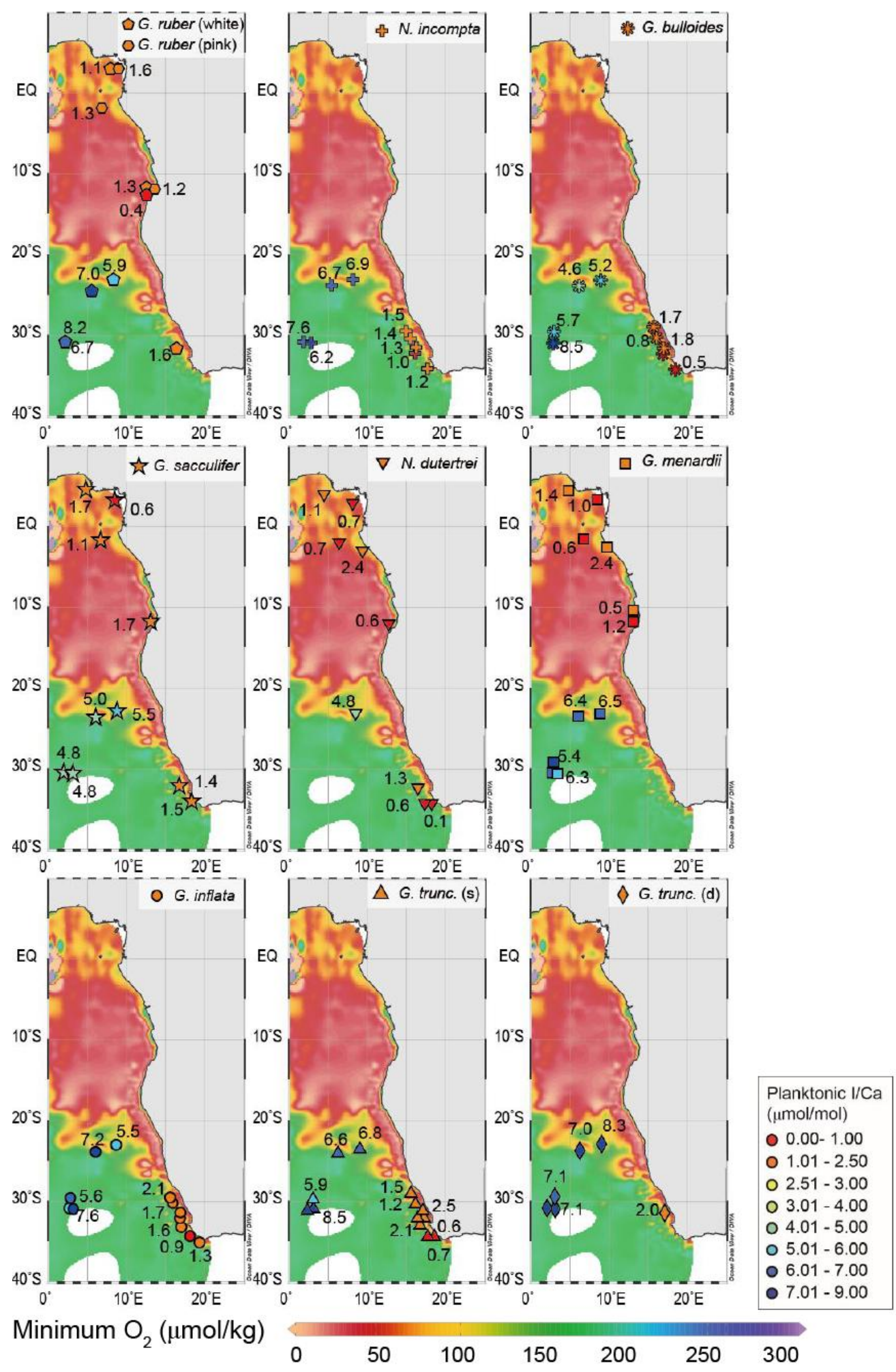

Fig. 3. Core-top planktic I/Ca spatial distribution maps. Background maps show the minimum $\mathrm{O}_{2}$ concentrations in the water column. Numbers next to the symbols show the planktic I/Ca values. 


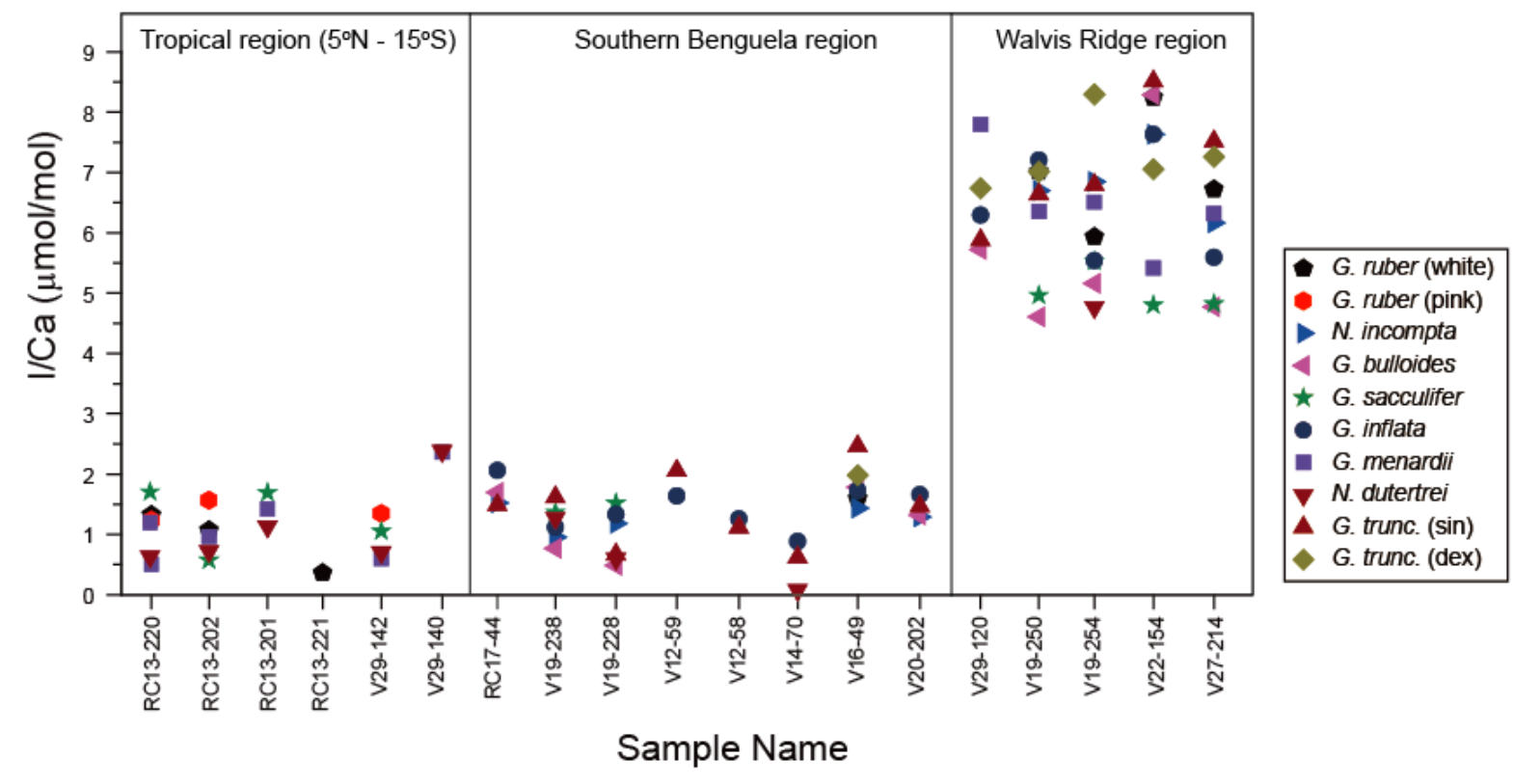

394

395

Fig. 4. Planktic I/Ca in core-top samples. The locations of the three regions are shown in Fig. $2 \mathrm{a}$. 

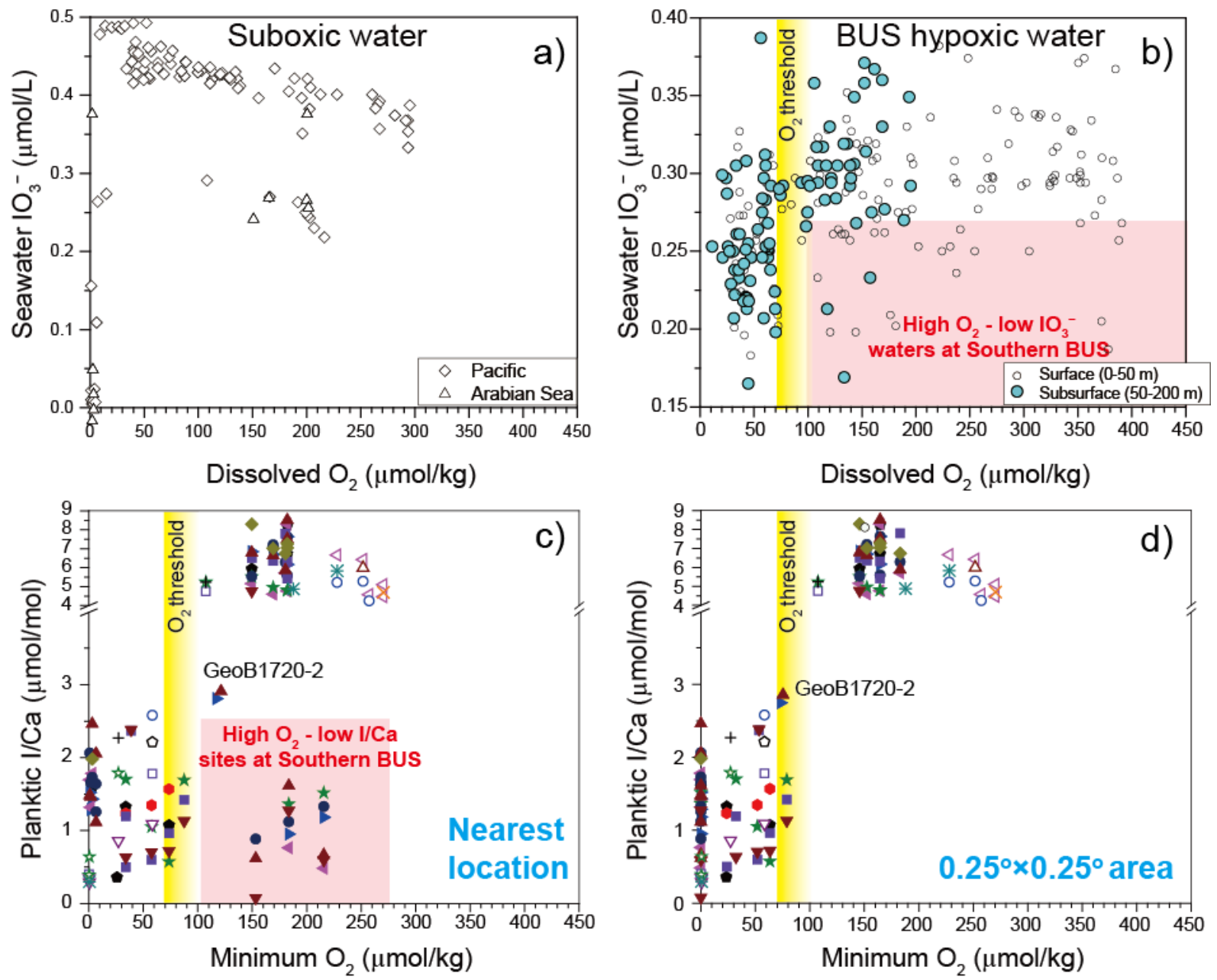

\begin{tabular}{|c|c|c|c|c|c|}
\hline - G. ruber (white) & G. ruber (pink) & N $N$ incompta & G. bulloides & $\star$ G. sacculifer & - G. inflata \\
\hline G. menardii & $\nabla N$. dutertrei & A G. trunc. $(\sin )$ & G. trunc. (dex) & $+P$. obliquiloculata & * O. universa \\
\hline
\end{tabular}

Fig. 5. a). Dissolved $\mathrm{IO}_{3}{ }^{-}$vs. $\mathrm{O}_{2}$ in the Pacific and Indian Oceans (Farrenkopf and Luther, 2002; Huang et al., 2005; Rue et al., 1997). b) Dissolved $\mathrm{IO}_{3}{ }^{-}$vs. $\mathrm{O}_{2}$ in shelf waters in Southern BUS (Chapman, 1983). Depths of all water samples were $<200 \mathrm{~m}$, locations are shown in the yellow box in Fig. 1. c-d). Core-top planktic I/Ca vs. minimum $\mathrm{O}_{2}$ concentrations in the water column derived from the nearest location and within $0.25^{\circ} \times 0.25^{\circ}$ area in WOD2013. Closed symbols indicate new data in this study, and open ones denote published data (Lu et al., 2016). 


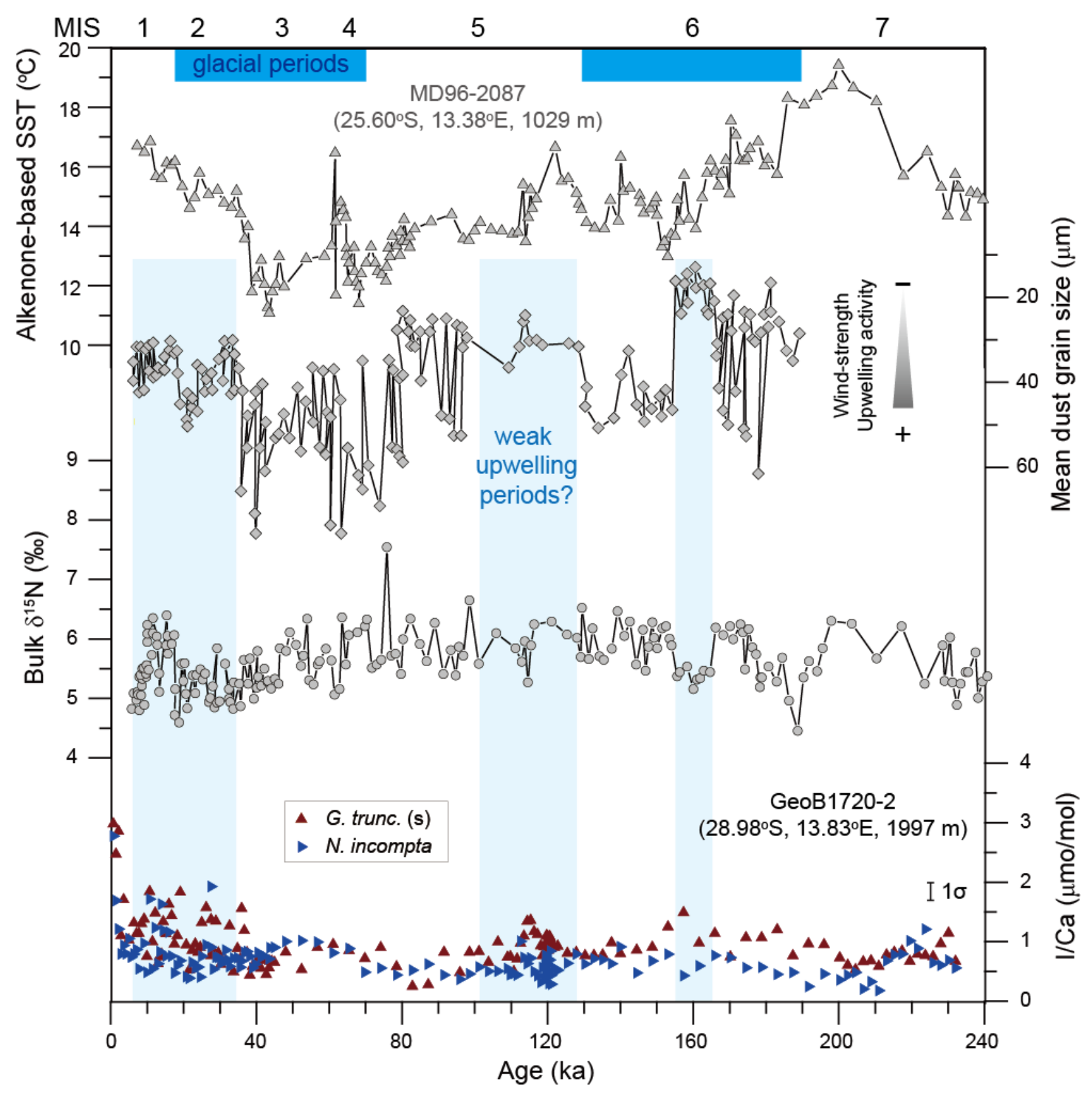

Fig. 6. Planktic I/Ca record at site GeoB1720-2 (this study), and alkenone-based SST, mean dust

411 grain size (Pichevin et al., 2005a), and bulk $\delta^{15} \mathrm{~N}$ at site MD96-2087 (Pichevin et al., 2005b).

412 Dark blue shadings indicate glacial periods, and light blue shadings indicate potential weak 413 upwelling periods.

414 


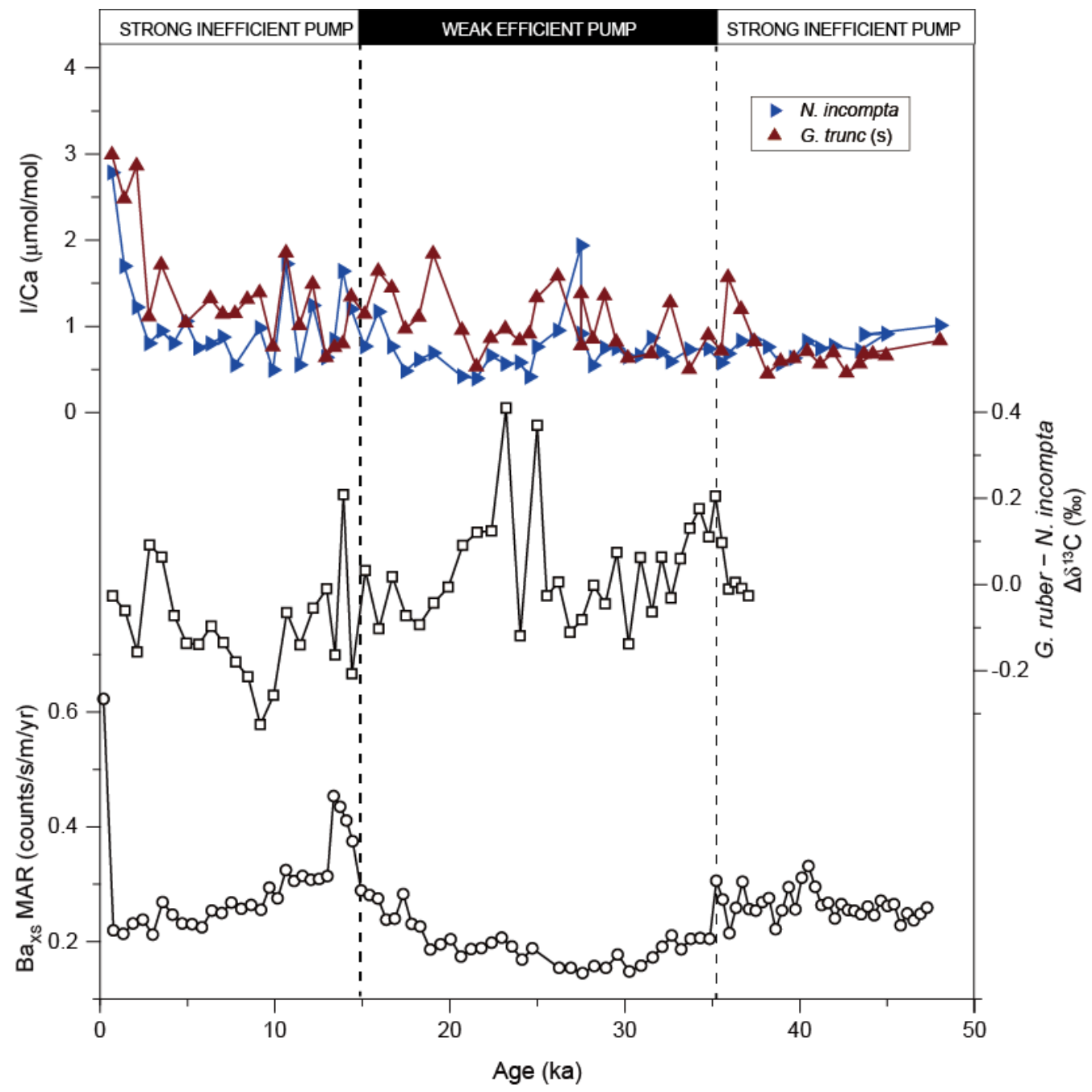

416

417

418

419

420 


\section{References}

Altabet, M. A., Pilskaln, C., Thunell, R., Pride, C., Sigman, D., Chavez, F., and Francois, R. (1999) The nitrogen isotope biogeochemistry of sinking particles from the margin of the Eastern North Pacific. Deep Sea Research Part I: Oceanographic Research Papers 46,655-679.

Anand, P., Elderfield, H., and Conte, M. H. (2003) Calibration of $\mathrm{Mg} / \mathrm{Ca}$ thermometry in planktonic foraminifera from a sediment trap time series. Paleoceanography 18,1050.

Bianchi, D., Weber, T. S., Kiko, R., and Deutsch, C. (2018) Global niche of marine anaerobic metabolisms expanded by particle microenvironments. Nature Geoscience 11,263-268.

Bonin, P., Gilewicz, M., and Bertrand, J. (1989) Effects of oxygen on each step of denitrification on Pseudomonas nautica. Canadian Journal of Microbiology 35,1061-1064.

Boyer, T. P., Antonov, J. I., Baranova, O. K., Coleman, C., Garcia, H. E., Grodsky, A., Johnson, D. R., Locarnini, R. A., Mishonov, A. V., O'Brien, T. D., Paver, C. R., Reagan, J. R., Seidov, D., Smolyar, I. V., and Zweng, M. M., (2013), World Ocean Database 2013, NOAA Atlas NESDIS 72, Silver Spring, MD, 209 p.:

Chance, R., Baker, A. R., Carpenter, L., and Jickells, T. D. (2014) The distribution of iodide at the sea surface. Environmental Science: Processes \& Impacts 16,1841-1859.

Chance, R., Malin, G., Jickells, T., and Baker, A. R. (2007) Reduction of iodate to iodide by cold water diatom cultures. Marine Chemistry 105,169-180.

Chapman, P. (1983) Changes in iodine speciation in the Benguela Current upwelling system. Deep Sea Research Part A. Oceanographic Research Papers 30,1247-1259.

Chapman, P., and Shannon, L. (1985) The Benguela ecosystem. Part II. Chemistry and related processes. Oceanography and Marine Biology. An Annual Review 23,183-251.

Chapman, P., and Truesdale, V. W. (2011) Preliminary evidence for iodate reduction in bottom waters of the Gulf of Mexico during an hypoxic event. Aquatic geochemistry 17,671-695.

Dickson, A. J., Beer, C. J., Dempsey, C., Maslin, M. A., Bendle, J. A., McClymont, E. L., and Pancost, R. D. (2009) Oceanic forcing of the Marine Isotope Stage 11 interglacial. Nature Geoscience 2,428.

Dickson, A. J., Leng, M. J., Maslin, M. A., Sloane, H. J., Green, J., Bendle, J. A., McClymont, E. L., and Pancost, R. D. (2010) Atlantic overturning circulation and Agulhas leakage influences on southeast Atlantic upper ocean hydrography during marine isotope stage 11. Paleoceanography 25,PA3208.

Farmer, E. C., Demenocal, P. B., and Marchitto, T. M. (2005) Holocene and deglacial ocean temperature variability in the Benguela upwelling region: Implications for low- latitude atmospheric circulation. Paleoceanography 20,PA2018.

Farrenkopf, A. M., Dollhopf, M. E., Chadhain, S. N., Luther III, G. W., and Nealson, K. H. (1997) Reduction of iodate in seawater during Arabian Sea shipboard incubations and in laboratory cultures of the marine bacterium Shewanella putrefaciens strain MR-4. Marine Chemistry 57,347-354.

Farrenkopf, A. M., and Luther, G. W. (2002) Iodine chemistry reflects productivity and denitrification in the Arabian Sea: evidence for flux of dissolved species from sediments of western India into the OMZ. Deep Sea Research Part II: Topical Studies in Oceanography 49,2303-2318.

Feng, X., and Redfern, S. A. (2018) Iodate in calcite, aragonite and vaterite CaCO3: Insights from first-principles calculations and implications for the I/Ca geochemical proxy. Geochimica et Cosmochimica Acta 236,351-360. 
Galbraith, E. D., and Jaccard, S. L. (2015) Deglacial weakening of the oceanic soft tissue pump: global constraints from sedimentary nitrogen isotopes and oxygenation proxies. Quaternary Science Reviews 109,38-48.

Galbraith, E. D., Kienast, M., Albuquerque, A. L., Altabet, M. A., Batista, F., Bianchi, D., Calvert, S. E., Contreras, S., Crosta, X., and De Pol-Holz, R. (2013) The acceleration of oceanic denitrification during deglacial warming. Nature geoscience 6,579.

Galbraith, E. D., Kienast, M., Jaccard, S. L., Pedersen, T. F., Brunelle, B. G., Sigman, D. M., and Kiefer, T. (2008) Consistent relationship between global climate and surface nitrate utilization in the western subarctic Pacific throughout the last $500 \mathrm{ka}$. Paleoceanography and Paleoclimatology 23,PA2212.

Ganesh, S., Parris, D. J., DeLong, E. F., and Stewart, F. J. (2014) Metagenomic analysis of size-fractionated picoplankton in a marine oxygen minimum zone. The ISME journal $\mathbf{8}, 187$.

Hoogakker, B. A., Lu, Z., Umling, N., Jones, L., Zhou, X., Rickaby, R. E., Thunell, R., Cartapanis, O., and Galbraith, E. (2018) Glacial expansion of oxygen-depleted seawater in the eastern tropical Pacific. Nature 562,410.

Huang, Z., Ito, K., Morita, I., Yokota, K., Fukushi, K., Timerbaev, A. R., Watanabe, S., and Hirokawa, T. (2005) Sensitive monitoring of iodine species in sea water using capillary electrophoresis: vertical profiles of dissolved iodine in the Pacific Ocean. Journal of Environmental Monitoring 7,804-808.

Hutchings, L., Van der Lingen, C., Shannon, L., Crawford, R., Verheye, H., Bartholomae, C., Van der Plas, A., Louw, D., Kreiner, A., and Ostrowski, M. (2009) The Benguela Current: An ecosystem of four components. Progress in Oceanography 83,15-32.

Jarre, A., Hutchings, L., Crichton, M., Wieland, K., Lamont, T., Blamey, L., Illert, C., Hill, E., and van den Berg, M. (2015) Oxygen- depleted bottom waters along the west coast of S outh A frica, 1950-2011. Fisheries Oceanography 24,56-73.

Kuroyanagi, A., da Rocha, R. E., Bijma, J., Spero, H. J., Russell, A. D., Eggins, S. M., and Kawahata, H. (2013) Effect of dissolved oxygen concentration on planktonic foraminifera through laboratory culture experiments and implications for oceanic anoxic events. Marine Micropaleontology 101,28-32.

Kuroyanagi, A., Toyofuku, T., Nagai, Y., Kimoto, K., Nishi, H., Takashima, R., and Kawahata, H. (2019) Effect of euxinic conditions on planktic foraminifers: culture experiments and implications for past and future environments. . Paleoceanography and Paleoclimatology 34,54-62.

Lamont, T., Hutchings, L., Van Den Berg, M., Goschen, W., and Barlow, R. (2015) Hydrographic variability in the St. Helena Bay region of the southern Benguela ecosystem. Journal of Geophysical Research: Oceans 120,2920-2944.

Lisiecki, L. E., and Raymo, M. E. (2005) A Pliocene- Pleistocene stack of 57 globally distributed benthic $\delta 180$ records. Paleoceanography 20,PA1003.

Lu, W., Ridgwell, A., Thomas, E., Hardisty, D., Luo, G., Algeo, T., Saltzman, M., Gill, B., Shen, Y., Ling, H., Edwards, C., Whalen, M., Zhou, X., Gutchess, K., Jin, L., Rickaby, R., Jenkyns, H., Lyons, T., Lenton, T., Kump, L., and Lu, Z. (2018) Late inception of a resiliently oxygenated upper ocean. Science 361,174-177.

Lu, Z., Hoogakker, B. A., Hillenbrand, C.-D., Zhou, X., Thomas, E., Gutchess, K. M., Lu, W., Jones, L., and Rickaby, R. E. (2016) Oxygen depletion recorded in upper waters of the glacial Southern Ocean. Nature communications $\mathbf{7 , 1 1 1 4 6 .}$

Lu, Z., Jenkyns, H. C., and Rickaby, R. E. (2010) Iodine to calcium ratios in marine carbonate as a paleo-redox proxy during oceanic anoxic events. Geology 38,1107-1110.

McKay, C., Filipsson, H., Romero, O., Stuut, J. B., and Björck, S. (2016) The interplay between the surface and 
bottom water environment within the Benguela Upwelling System over the last $70 \mathrm{ka}$. Paleoceanography 31,266-285.

Mollenhauer, G., Eglinton, T., Ohkouchi, N., Schneider, R., Müller, P., Grootes, P., and Rullkötter, J. (2003) Asynchronous alkenone and foraminifera records from the Benguela Upwelling System. Geochimica et Cosmochimica Acta 67,2157-2171.

Mollenhauer, G., Schneider, R. R., Müller, P. J., Spieß, V., and Wefer, G. (2002) Glacial/interglacial variablity in the Benguela upwelling system: Spatial distribution and budgets of organic carbon accumulation. Global Biogeochemical Cycles 16,1134.

Pichevin, L., Cremer, M., Giraudeau, J., and Bertrand, P. (2005a) A 190 ky record of lithogenic grain-size on the Namibian slope: Forging a tight link between past wind-strength and coastal upwelling dynamics. Marine Geology 218,81-96.

Pichevin, L., Martinez, P., Bertrand, P., Schneider, R., Giraudeau, J., and Emeis, K. (2005b) Nitrogen cycling on the Namibian shelf and slope over the last two climatic cycles: Local and global forcings. Paleoceanography 20,PA2006.

Pitcher, G. C., Probyn, T. A., du Randt, A., Lucas, A., Bernard, S., Evers- King, H., Lamont, T., and Hutchings, L. (2014) Dynamics of oxygen depletion in the nearshore of a coastal embayment of the southern Benguela upwelling system. Journal of Geophysical Research: Oceans 119,2183-2200.

Podder, J., Lin, J., Sun, W., Botis, S., Tse, J., Chen, N., Hu, Y., Li, D., Seaman, J., and Pan, Y. (2017) Iodate in calcite and vaterite: Insights from synchrotron X-ray absorption spectroscopy and first-principles calculations. Geochimica et Cosmochimica Acta 198,218-228.

Robinson, R., Martinez, P., Pena, L., and Cacho, I. (2009) Nitrogen isotopic evidence for deglacial changes in nutrient supply in the eastern equatorial Pacific. Paleoceanography 24,PA4213.

Romero, O., Crosta, X., Kim, J.-H., Pichevin, L., and Crespin, J. (2015) Rapid longitudinal migrations of the filament front off Namibia (SE Atlantic) during the past 70 kyr. Global and Planetary Change 125,1-12.

Rue, E. L., Smith, G. J., Cutter, G. A., and Bruland, K. W. (1997) The response of trace element redox couples to suboxic conditions in the water column. Deep Sea Research Part I: Oceanographic Research Papers 44,113-134.

Schlitzer, R., (2018), Ocean Data View (http://odv.awi.de).

Schmidtko, S., Stramma, L., and Visbeck, M. (2017) Decline in global oceanic oxygen content during the past five decades. Nature 542,335.

Shannon, L., and Nelson, G. (1996), The Benguela: large scale features and processes and system variability, The South Atlantic, Springer, p. 163-210.

Stramma, L., and England, M. (1999) On the water masses and mean circulation of the South Atlantic Ocean. Journal of Geophysical Research: Oceans 104,20863-20883.

Truesdale, V., and Bailey, G. (2000) Dissolved iodate and total iodine during an extreme hypoxic event in the Southern Benguela system. Estuarine, Coastal and Shelf Science 50,751-760.

Tsunogai, S., and Sase, T., Formation of iodide-iodine in the ocean, in Proceedings Deep Sea Research and Oceanographic Abstracts1969, Volume 16, Elsevier, p. 489-496.

Ulloa, O., Canfield, D. E., DeLong, E. F., Letelier, R. M., and Stewart, F. J. (2012) Microbial oceanography of anoxic oxygen minimum zones. Proceedings of the National Academy of Sciences 109,15996-16003.

Wada, E., and Hattori, A., (1990), Nitrogen in the sea: forms, abundance, and rate processes, CRC press. 
543 Waite, T. J., and Truesdale, V. W. (2003) Iodate reduction by Isochrysis galbana is relatively insensitive to 544 de-activation of nitrate reductase activity-are phytoplankton really responsible for iodate reduction in $545 \quad$ seawater? Marine chemistry 81,137-148.

546 Wolgast, D., Carlucci, A., and Bauer, J. (1998) Nitrate respiration associated with detrital aggregates in aerobic bottom waters of the abyssal NE Pacific. Deep Sea Research Part II: Topical Studies in Oceanography 45,881-892.

549 Wong, G. T., and Hung, C.-C. (2001) Speciation of dissolved iodine: integrating nitrate uptake over time in the oceans. Continental Shelf Research 21,113-128.

551 Zhou, X., Thomas, E., Rickaby, R. E., Winguth, A. M., and Lu, Z. (2014) I/Ca evidence for upper ocean deoxygenation during the PETM. Paleoceanography 29,964-975. 